\title{
KLAIPĖDOS UNIVERSITETE APGINTA DISERTACIJA KARINE TEMATIKA
}

\author{
Renata Rachmanovaite \\ Klaipedos universiteto Baltijos regiono istorijos \\ ir archeologijos institutas
}

DOI: https://doi.org/10.47459/ka.2021.36.8

2021 metų balandžio 16 dieną Klaipèdos universitete nuotoliniu būdu (kaip jau tapo ịprasta pandemijos sąlygomis) buvo apginta Egidijaus Papečkio daktaro disertacija „Lietuvos Respublikos gynybinès galios transformacija 1990-2004 m.: tarp individualios ir kolektyvinès gynybos“ (darbo vadovas - prof. dr. Vygantas Vareikis). Verta pažymėti, kad Egidijus Papečkys ne tiktai vykdo mokslinius Lietuvos gynybinès galios tyrimus, bet ir nuolatos publikuoja analitinius straipsnius šiuolaikinès karybos klausimais Lietuvos ir užsienio šalių žiniasklaidoje, o nuo 2015 metų dirba Lietuvos šaulių sąjungoje. Šių metų pradžioje jis tapo Suvalkijos šaulių 4-osios rinktinès vadu.

Egidijaus Papečkio parengta ir apginta disertacija ìsikomponuoja i Klaipedos universiteto Baltijos regiono istorijos ir archeologijos institute vykdomus karo istorijos tyrimus, iš kurių galima išskirti itin produktyvaus karo istoriko Vytauto Jokubausko, kuris pirmasis apgynè mokslo daktaro disertaciją karine tematika Klaipedos universitete, darbus ${ }^{1}$. Klaipédos universitete šiuo metu rengiamos dar dvi mokslo daktaro disertacijos, susijusios su tarpukario Lietuvos Respublikos kariuomenès istori$\mathrm{ja}^{2}$. Tačiau Egidijaus Papečkio mokslinis tyrimas unikalus tuo, jog jame

1 Išskirtinos monografijos: Jokubauskas V. „Mažųjų kariuomenių“ galia ir paramilitarizmas: tarpukario Lietuvos atvejis. Klaipeda, 2014; Jokubauskas V., Vaičenonis J., Vareikis V., Vitkus H. Valia priešintis: paramilitarizmas ir Lietuvos karinio saugumo problemos. Klaipėda, 2015; Safronovas V., Jokubauskas V., Vareikis V., Vitkus H. Didysis karas visuomenejje ir kultūroje: Lietuva ir Rytų Prūsija. Klaipèda, 2018; Jokubauskas V. Netiesioginis poveikis ir Lietuvos karinis saugumas 1919-1940 m. Klaipeda, 2019.

2 Jakštys G. Lietuvos karių kasdienybė karo ir taikos metu 1918-1940 m. (darbo vadovas - prof. dr. V. Vareikis). Sereičikas M. Civilių gyventojų patirtys Lietuvoje ginkluotų konfliktų metu (1918-1923) (darbo vadovas - dr. V. Jokubauskas). 
nagrinejjami neseni istoriniai įvykiai, kurių dalyviai ir veikiantys asmenys yra gyvi ir gali papasakoti savo įvykių versijas. Lietuvos karinės galios kūrimas ir kariuomenés formavimas po 1990 metų kompleksiškai tirtas dar nebuvo. Be to, kai kurie dokumentai, susiję su Lietuvos stojimu i NATO, ginkluotès įsigijimo aplinkybèmis po nepriklausomybès paskelbimo, tiktai neseniai buvo išslaptinti ir, kaip pažymejjo Egidijus Papečkys pristatydamas savo darbą, tyrimai, susiję su šių laikų gynyba, yra itin jautri sritis. Dalis su Lietuvos gynyba susijusios informacijos tebèra islaptinta ir ja nebuvo galimybės pasinaudoti. Nors dalis anksčiau įslaptintos arba riboto naudojimo informacijos šiandien išslaptinta (ypač tai sietina su tuo, kad, Lietuvai ịstojus į NATO, ankstesni su individualia gynyba susiję dokumentai bei duomenys tapo nebeaktualūs), ateis laikas, kai šie dokumentai bus sunaikinti. Tad reikia skubèti tirti šaltinius.

Pristatydamas savo darbą, disertantas paminèjo metodologinio pobūdžio problemą, kai dèl netolimos praeities „istorikas tarsi ir rizikuoja prarasti vieną iš savo metodologinių ịrankių - galimybę i ịvykius ir tiriamajji objektą pažvelgti iš saugios laiko distancijos. Tačiau, atsižvelgiant $\mathfrak{i}$ vis spartejjantị gyvenimo tempą, skaitmenizavimą ir moderniųjų technologijų skleidžiamas žinias, istorikai igauna naujas praeities vertinimo ir refleksijos galimybes, o laikas, reikalingas „istorinei distancijai“ nustatyti, vis labiau traukiasi. Antra vertus, kai kurie įvykiai yra tokie svarbūs valstybei ir visuomenei, kad jų istorinis vertinimas neturètų būti atidèliojamas teisinantis vien metodologiniu „istorinès distancijos“ nebuvimu ar teiginiais, kad dar neatejo laikas tyrinèti nesenos praeities įvykius“.

Pristatymo metu autorius nurode tyrimo tikslą - „nustatyti ir ivertinti, kokiu sprendimu, veiksmu ir aplinkybiu visuma sudare galimybes Lietuvos Respublikai per 1990-2004 m. laikotarpi iš kariniu požiūriu silpnos valstybès tapti Šiaurès Atlanto sajungos (NATO) nare, sukurti reikalavimus atitinkančias karines pajegas ir spręsti nacionalinio saugumo grésmes $^{\text {“3 }}$ - ir uždavinius: ịvertinti, kokių grèsmių ir gynybinio potencialo lauke atsidūrè atkūrusi nepriklausomybę Lietuvos Respublika ir kokių sprendimų imtasi pradiniame krašto apsaugos sistemos atkūrimo etape; išnagrinèti Lietuvos Respublikos sieki tapti NATO nare, ši procesą lèmusius politinius, karinius ir ekonominius veiksnius bei

3 Papečkys E. Lietuvos Respublikos gynybinès galios transformacija 1990-2004 m.: tarp individualios ir kolektyvinès gynybos. Daktaro disertacija. Klaipėda, 2021, p. 14. 
Rusijos darytą ịtaką; išanalizuoti krašto apsaugos sistemos raidą, karinès galios stiprinimą ir užsienio valstybių paramą, transformuojant ginkluotąsias pajejgas, siekiant atitikti NATO šalims narèms keliamus reikalavimus; išnagrinėti teritorinės gynybos, kaip ginkluotos valstybės gynybos pagrindo ir asimetrinio atsako, kūrimą, vystymą ir pokyčius, pereinant nuo individualios (be sąungininkų) prie kolektyvinès (Šiaurès Atlanto sąjungoje) gynybos principo ${ }^{4}$.

Autorius pateikè analitines išvadas, kurias trumpai referuosiu. Paskelbusi nepriklausomybę Lietuvos Respublika susidūrè su saugumo iššūkiais, o Aukščiausioje Taryboje kilusios diskusijos dèl Lietuvos gynybinès galios atkūrimo sutrukdè atkurti Krašto apsaugos ministeriją, kaip pirmosios Lietuvos Respublikos institucijos tęsejją. Atkuriant Lietuvos kariuomenę iš pradžių maskuotasi sporto ir techninių klubų veikla, svarbių objektų apsaugos poreikiu. Po $1991 \mathrm{~m}$. sausio ịvykių ir rugpjūčio pučo Lietuvos kariuomenè pradèta kurti atvirai, buvo suformuotos Sausumos, Oro ir Jūrų pajėgos. Lietuvos šaulių sąjungos vietą valstybės gynybos sistemoje užèmė Savanoriška krašto apsaugos tarnyba, kaip tikètasi, turejjusi tapti Nacionaline gvardija, bet ši tarnyba buvo politizuota, pasireiške ir priešprieša tarp po nepriklausomybès savo karinę karjerą pradejjusių karių ir karininkų, neretai neturinčių reikiamo karinio išsilavinimo, ir sovietineje kariuomenejje tarnavusių bei kariṇ̨ išsilavinimą ịgijusių karininkų, vadinamų „raudonaisiais pulkininkais“.

Krašto apsaugos sistemos apginklavimas buvo rimta problema iš pradžių dèl sovietinių jègos struktūrų, vèliau - dèl neoficialaus užsienio šalių embargo ir sunkios ekonominès padèties. 1993 m. išvedus Rusijos kariuomenę iš Lietuvos, atsirado prielaidos laisvai bendradarbiauti su užsienio šalimis gynybos srityje, gauti jų paramą, dalyvauti tarptautinèse taikos palaikymo operacijose.

Išvedus Rusijos kariuomenę iš Lietuvos, valstybės gynybinė galia pradèta konstruoti dviem lygiagrečiais vektoriais - vystant ir ginkluojant savo karines pajègas bei kuriant teritorinès gynybos koncepciją ir aktyviai siekiant tapti Šiaurès Atlanto sąjungos nare ir kolektyvinès gynybos sistemos dalimi.

NATO plètra ir Lietuvos siekis tapti Aljanso nare sulaukẻ kategoriško Rusijos Federacijos pasipriešinimo. Lietuva savo narystę NATO mate

4 Papečkys E. Ten pat, p.14. 
kaip grižimą i Vakarų demokratiją, o Rusija NATO plètroje ižvelgè kritinę grèsmę savo nacionaliniam saugumui. Todèl buvo daromas stiprus politinis spaudimas, siekiant sutrukdyti Lietuvai ir kitoms Baltijos šalims tapti NATO narėmis. JAV buvo pagrindinės Baltijos šalių narystės NATO siekio rèmejos. Lietuvos politinè valdžia èmèsi diplomatinių priemonių, skatinančių JAV dar aktyviau remti jos narystès NATO idejją.

Pradèjusi atkurti karinę galią „nuo nulio", Lietuva susidūrè su būtinybe apginkluoti ir aprūpinti karo technika savo karines pajegas. Todell labai svarbi tapo užsienio šalių karinè parama. Didžiosioms šalims vengiant konfrontuoti su Rusija, pirmosios pagalbą pradejo teikti Lenkija ir Čekija. Labai svarbią pagalbą, tiesa, ne kovos technika, teike neutrali Švedija. Visapusišką didelès apimties pagalbą teikè JAV. Proveržiu tapo JAV ir Baltijos chartija, kurią pasirašius iš JAV pradèta gauti ir kovinių ginklų - šautuvų, modernių prieštankinių ir priešlektuvinių priemonių. Vèliau karinè NATO valstybių ir Švedijos parama tapo tiksliné, planinga ir nukreipta $\mathfrak{i}$ konkrečių tikslų, užsibrèžtų 1999-2003 m. pasirengimo narystei programose, pasiekimą. Kiekvienai kariuomenei būtini artilerijos, oro gynybos pajègumai buvo sukurti ir išvystyti tik užsienio šalių paramos dèka.

Egidijaus Papečkio tyrimą, vykdytą nuo 2014 metų, vertino disertacijos gynimo taryba, kurią sudare jos pirmininkas prof. dr. Jonas Vaičenonis (Vytauto Didžiojo universitetas) ir nariai - prof. dr. Gediminas Vitkus (Vilniaus universitetas), dr. Gintautas Surgailis (Generolo Jono Žemaičio Lietuvos karo akademija), dr. Deividas Šlekys (Vilniaus universitetas) ir dr. Hektoras Vitkus (Klaipédos universitetas).

Trumpiausią apibendrinamąji atsiliepimą pateikè dr. Gintautas Surgailis, kuris pabreže temos, kurios naujumas nekelia jokių abejonių, aktualumą, nes šiuolaikinès kariuomenès istorijai skirtų mokslo darbų yra palyginti mažai. Jo nuomone, tiriamojo laikotarpio pasirinkimas buvo logiškas, nes Lietuvos įstojimas i NATO Lietuvos kariuomenès istorijoje yra labai aiški riba, kai nuo individualios gynybos prasidejo naujas kolektyvinès gynybos etapas. G. Surgailis padare išvadą, kad E. Papečkys disertacijoje iškeltus uždavinius igyvendino, ypač gerą ịspūdị jam paliko darbo ịvadas, kuriame problemiškai išanalizuota istoriografija. Prof. dr. Gediminas Vitkus buvo kritiškesnis ir pažymėjo, kad kai kurias disertacijoje nagrinètas problemas (NATO istorines transformacijas, politinius debatus Lietuvoje, Rusijos bandymus kliudyti Lietuvai siekti narystės NATO) tematiškai galima priskirti gynybinei galiai. G. Vitkus 
taip pat pastebejo, kad disertacijoje autorius pagrindinès sąvokos - $g y$ nybine galia - išsamiau neaptarè, o vadovavosi ne tikslia eksplicitiška, bet intuityvia samprata. Ir tai lèmé, kad darbe aptariami politiniai procesai arba teritoriné gynyba ne visada buvo susieti su pagrindiniu tyrimo objektu - gynybine galia. G. Vitkus išskyrè E. Papečkio disertacijos naujumą ir tai, kad didžiausia pridedamoji darbo vertẻ būtų platus Lietuvos Respublikos krašto apsaugos ministerijos archyvo medžiagos naudojimas ir išnaudota galimybẻ paimti interviu iš 1990-2004 m. įvykių dalyvių, kurie buvo atsakingi už sprendimų prièmimą didinant Lietuvos gynybinę galią. Anot G. Vitkaus, puikiai atskleisti disertacijos skyriai, skirti kariuomenès materialiniam techniniam aprūpinimui, plačiai ir tinkamai naudojami istorinių šaltinių tyrimai, taikant statistinị metodą ir kritinę istoriografinès medžiagos analizę. Nors šiame darbe buvo naudoti politiniai dokumentai, o politikų kalbų analizė yra ịprastas politikos mokslų atstovų taikomas įrankis, jis taip pat būdingas ir istorikų tyrimams. Tačiau vien šio metodo naudojimas dar nereiškia, kad pats darbas yra tarpdisciplininis - pareiškè G.Vitkus.

Dr. Deividas Šlekys taip pat atkreipé dėmesị i E. Papečkio darbo tarpdiscipliniškumą, nes buvo pateiktos socialinių ir humanitarinių mokslų ¡žvalgos. D. Šlekio kritikos nusipelnè tai, kad disertacijoje stokoja konceptualesnio gylio pagrindinè darbo ašis - gynybinès galios samprata. Iš to buvo suformuluotas mokslinès diskusijos klausimas: „Kodèl gynybinè galia yra tiriama apžvelgiant tik organizacinius, techninius - ginkluotès, politinius ir truputị doktrininius aspektus?" D. Šlekys dèmesị atkreipè ir $\mathfrak{i}$ tai, kad labai daug (gal net per daug, palyginti su kituose skyriuose tiriamomis problemomis ir joms skiriamu dèmesiu) vietos užima materialinio aprūpinimo ir ginkluotès tema. Jis taip pat pasigedo informacijos apie 1990 metais Švedijos suteiktą pagalbą Lietuvai ir tokị žingsnị lydinčios politikos analizès, politinių niuansų aptarimo paskutiniais metais prieš narystę NATO.

Dr. Hektoro Vitkaus nuomone, ypač svarbu tai, kaip disertacijos autorius pagrindè savo darbo naujumą ir aktualumą, nes „NATO plètros ir Lietuvos stojimo $\mathfrak{i}$ ši kolektyvinès gynybos aljansą aspektai“ pirmą kartą tiriami ne kaip atskiri istoriniai ir politiniai reiškiniai, bet „kaip sinergiškas istorinis procesas, tarpdisciplininiu požiūriu ịvertinant politinio dèmens poveikị ir svarbą kariniam veiksniui ir atvirkščiai“. Pasak dr. H. Vitkaus, pagirtina ir tai, kad disertacijos autorius neapejo Holo- 
kausto restitucijos temos (ne tik nacių okupacijos metais nusavinto žydų turto grąžinimo, bet ir politinių ịsipareigojimų Holokausto istorinès atminties ir atminimo kultūros formavimo prasmèmis) kaip Lietuvai (bei kitoms euroatlantinès integracijos siekusioms šalims) ypač problemiško iššūkio, siekiant ịstoti ị NATO. Visgi H. Vitkus E. Papečkio disertacijoje pasigedo nuodugnesnio Lietuvos Respublikos gynybinès galios transformacijos 1990-2004 m. proceso aprašymo.

Užbaigdamas disertacijos gynimo tarybos narių pranešimus, jos pirmininkas prof. dr. Jonas Vaičenonis išsakè pastabą, kad prie plačios faktografinės medžiagos kai kur, jo nuomone, trūko platesnių ir drąsesnių autoriaus komentarų ir interpretacijų vertinant faktus proceso atžvilgiu. Pasigesta ir Lietuvos palyginimo su kitomis šalimis, vykdant iškeltus 2 proc. BVP rodiklio reikalavimus. Kaip ir kiti tarybos nariai, J. Vaičenonis pažymėjo disertacijos naujumą ir tarpdiscipliniškumą ir pabrèžè, kad darbe išryškinamos galimos tolesnių tyrimų perspektyvos, matant Lietuvos atvejo lyginimo su NATO ir ne NATO šalių kariuomenėmis galimybę, analizuojant pati procesą ir karybos sampratos kitimą nuo konvencinio link hibridinio karo, ịvardijant šalis, kurios tiesiogiai ar netiesiogiai buvo kontroliuojamos Sovietų Sąjungos. Disertantas pagirtas už tai, kad surinko trylikos asmenų interviu medžiagą, kuria remiantis buvo galima rekonstruoti kai kuriuos tyrimo epizodus, menkai pagrindžiamus dokumentine medžiaga.

Po E. Papečkio atsakomosios kalbos dèl tarybos narių iškeltų problemų ir mokslinès diskusijos bei neilgos pertraukèlès taryba vienbalsiai nutarè suteikti E. Papečkiui humanitarinių mokslų daktaro (istorijos ir archeologijos sritis) vardą.

Tikètina, kad E. Papečkio disertacijoje pateiktos ịžvalgos gali prisidèti prie istorijos ir politikos mokslų tyrimų, susijusių su karyba bendrąja prasme, Lietuvos kariuomenès veikla nuo 1990 metų ir Lietuvos saugumo veiksniais. 